\title{
Experimental Investigation on the Spray Combustion Produced by an External Mixing Air Assist Atomizer
}

\author{
\{A. K. Khodir, Gaber M. Asar, S. M. El-Behery, W. A. El-Askary $\}^{\dagger}$
}

\begin{abstract}
The combustion of spray of liquid fuels has a significant importance in the industry field. This paper describes an experimental study to understand and analyze the flame structure of a light diesel fuel. A special design of an external mixing air assist atomizer is used for the atomization. The atomizer installed through burner tube. Combustion tests in a small scale laboratory furnace are carried out to select the optimum operating conditions for good combustion and low emissions. The emissions $\left(\mathrm{CO}\right.$ and $\left.\mathrm{NO}_{\mathrm{x}}\right)$, combustion efficiency, axial and radial inflame temperature profiles and the heat transfer distribution for the water jacket are measured at various operating conditions. Visual observation of free jet flames was taken over wide ranges of atomizing air pressure. It is found that increasing the atomizing air pressure with the same air to fuel ratio, leads to decreasing the amount of heat flux to the cooling water jacket, decreasing in the combustion efficiency and increasing in $\mathrm{CO}$ and $\mathrm{NO}_{\mathrm{x}}$ emissions. It is noticed that increasing in air to fuel ratio (A/F) at the same fuel flow rate leads to decreasing in $\mathrm{CO}$ and $\mathrm{NO}_{\mathrm{x}}$ emissions.
\end{abstract}

Keywords: An external mixing air assist atomizer; Spray combustion; Emissions; Atomizing air pressure; Inflame temperature; Flame length.

\section{Introduction}

Spray combustion of liquid fuels provide a considerable part of the world energy resources. Considerable percentages of fuels are in a liquid phase such as diesel, vegetable oils and biodiesel. Global warming and climate change have been increased remarkably, due to emissions from the combustion applications. Industrialized countries are forced to pay attention to the issue of emission reduction in spite of their increasing demand of energy. For these reasons, it is important to increase the combustion efficiency and decrease pollutant emissions.

The combustion of liquid fuels occurs using atomizers which converting the bulk liquid into a spray of droplets. These droplets heated up during ignition and converted to liquid vapor. The vapor mixes with the air within the flammability limits and the combustion occurs [1]. AbuQudais and Gassan [2] reported an extensive experimental study for the atomization and direct combustion of a liquid fuel olive-cake (OC) slurry. The liquid fuel is atomized using a twin fluid atomizer. Three angles of swirl $\left(0^{\circ}, 30^{\circ}\right.$ and $\left.45^{\circ}\right)$ have been used for the atomizing air and the fuel was fed from an overhead tank by gravity. It is found that the rate of heat transfer to the water jacket of the combustor and the combustion efficiency are improved when the percentage of $\mathrm{OC}$ in the diesel fuel is increased to 7 percent by weight.

\section{Ahmed31791@gmail.com}

Mechanical Power Eng. Dept., Faculty of Eng., Menoufia University, Egypt. 
Costa et al. [3] carried out an extensive experimental study on the combustion of a heavy fuel oil-fired furnace. Two distinct heavy fuel oil sprays are generated by a twin-fluid atomizer. It is concluded that there are a strong relation between the non-reacting spray and the spray combustion (flames). The reported data provide a better understanding of the relationship between spray quality and combustion performance and assist the validation of mathematical models for prediction of heavy fuel oil combustion. In liquid fuel combustion, most of droplets do not burn individually, but the evaporation from all droplets forms a cloud of vapor which burns in similar way to the turbulent gas diffusion flame [4].

Rosa et al. [5] studied experimentally the effect of oil fuel properties on droplet size distribution and spray combustion. Two oil fuels are atomized and burn at different temperatures, subsequently different viscosities. It is found that the highest viscosity fuel produces a droplet size range about double that of the lower viscosity fuel at identical conditions. The direct flame photographs of free burning are taken and it is found that the whole flame of heavy viscous oil is much less uniformly luminous than the flame of the lighter oil. Also, it is noticed that the peak temperature of the light fuel is $200 \mathrm{~K}$ higher than that of the heavier fuel. Also, the differences in flame characteristics are related to the differences in droplet size distribution which obtained from the cold study of the spray.

Rafal et al. [6] investigated experimentally the effect of turbulence properties on the spray flame characteristics particularly, the vaporization, mixing and burning of liquid fuel (kerosene). The turbulence characteristics are changed through a grid placed at some distance from the air assist atomizer exit. The temperature measurements show that the maximum temperature increases with increasing the mesh size. Also, it is noticed that the faster evaporation does not necessarily lead to faster combustion.

Pereira et al, [7] studied experimentally the combustion of biodiesel in a large-scale laboratory furnace. The tests are carried out to evaluate the feasibility of using biodiesel in industrial furnaces. For comparison purposes, petroleum-based diesel is also used as a fuel. The liquid fuels (biodiesel and diesel) are supplied to the burner with the aid of a nitrogen-pressurized tank. It is found that NOx emissions from biodiesel combustion are always lower than those from diesel combustion.

Padwal and Mishra et al. [8] studied experimentally the characteristics of unconfined gelled JetA1 spray flames. The results are compared with ungelled spray flames. It is found that gelled Jet A1 spray flames are shorter than ungelled Jet A1 spray flames. Verdier et al. [9] reported an experimental study for the local flame structures and fuel droplet properties of $n$-heptane spray jet flame. The fuel is atomized using a simplex fuel injector. The fuel droplet temperatures were obtained by Global Rainbow Refractometry Technique (GRT). The profile across the flame front presents a steep gradient that allows distinguishing the temperature of droplets situated in the burnt gases and in the fresh gases.

The differences in the spray characteristics lead to changes in the fuel vapor distribution inside the flame. The consequences are important variations of the flame characteristics and of the emission of gaseous and solid pollutants [13]. Abu-Qudais [14] studied experimentally performance and emissions characteristics of a cylindrical water cooled furnace using nonpetroleum (shale oil) fuel. The rate of heat transfer to the water jacket of the water cooled furnace is improved in the case of shale oil compared to Diesel fuel when they are tested under the same conditions. Also, Barreiros et al. [15] studied experimentally prediction of the near burner region and measurements of $\mathrm{NO}$, and particulate emissions in heavy fuel oil spray flames. Baghdar Hosseini [16] has reported an experimental comparison of combustion characteristics and pollutant emissions of gas oil and biodiesel. Akash [17] determined the 
combustion performance and gas emission of diesel fuel, kerosene and various mixtures of diesel fuel and kerosene in a horizontally positioned cylindrical furnace. It is found that the best results when a fuel blend of $75 \%$ kerosene and $25 \%$ diesel was prepared and burned in the unit. Twin fluid atomizers are commonly used in many propulsion and power systems [18]. Nitrogen, Argon, and $\mathrm{CO}$ were used as the atomizing gas in an air-assist! fuel nozzle to determine the effect of these gases on droplet size, number density, and velocity distribution in kerosene spray [19].

The introduction of swirl to the combustion air modifies the droplet/air velocity field in addition to the spatial distribution of droplet size and number density. Larger droplets are transported downstream relatively unperturbed by the surrounding air stream while smaller droplets are entrained by the recirculating aerodynamic pattern. In addition, observed instabilities during liquid jet breakup appear to result in droplet clustering further downstream. The interaction between the fuel droplets and air flow field is therefore a process that significantly affects the overall characteristics of spray flames. Regulation of fuel/air interactions can mitigate fuel losses into the surrounding environment as well as control flame stability [20].

It can be concluded from the previous studies that the external mixing air assist atomizer plays an important role in the scientific research. The quality of fuel atomization is very important to improve the combustion process of any liquid fuel. Bad designed atomizer nozzles may lead to clogging or accelerated erosion of the nozzle. Also, the poor design of atomizer generates large droplets which reduce the combustion efficiency. The mixing technique of the atomized spray with the combustion air also affects the flame temperature distribution and concentrations of pollutant formed.

This paper investigates experimentally the spray combustion produced by a specially designed external mixing air assist atomizer at different operating conditions.

\section{Methodology}

A confined spray combustion facility is assembled at faculty of engineering (Menoufia University). The experimental setup is designed and constructed to allow measuring the inflame temperature, emissions, heat flux and exhaust temperature. An air-assist atomizer is used to atomize the diesel fuel. The physical properties of an Egyptian diesel fuel are given in Table (1) which obtained from Misr Petrollem Company. In the initial tests the flame characteristics is obtained at different values of atomizing air pressures (1, 1.5 and 2 bar) at constant air to fuel ratio, then the visual observation of the unconfined flames are analyzed using direct pictures in free air. In the remaining tests the characteristics obtained at different values of air to fuel ratios $\left(15,20,25,30 \mathrm{~kg}_{\text {air }} / \mathrm{kg}_{\text {fuel }}\right)$ at the same atomizing air pressure.

\section{Experimental Facilities}

An experimental setup is designed and constructed to provide experimental data of spray flame combustion. The test rig shown schematically in Fig. 1 consists of a horizontal small-scale cylindrical furnace (1) equipped with an external mixing air assist atomizer (2) which installed through burner (3). The combustion air is supplied to the burner tube from a centrifugal Blower (4). The combustion air flow rate regulated through a globe valve (5) and measured using calibrated orifice meter (6). The atomizing air is supplied from a large tank (7) with volume 7 $\mathrm{m}^{3}$ and charged with screw compressor (8). The atomizing air pressure is regulated through a pressure regulator (9) and its flow rate is measured using calibrated orifice meter (10). The liquid fuel is supplied from a tank (11) pressurized by a compressed air. The fuel tank pressure 
is regulated using a pressure regulator (12). The fuel filtered through a filter (13) to prevent the atomizer blockage, hence keep a constant fuel flow rate. A pressure relief valve (14) is used as a safety valve and helps in keeping constant air pressure above the liquid fuel surface. The combustor is an insulated horizontal cylindrical water cooled flame tube of $480 \mathrm{~mm}$ inner diameter and $1500 \mathrm{~mm}$ length manufactured of thick steel sheet of $5 \mathrm{~mm}$ thickness. The cylindrical flame tube is cooled by a water circular jacket of $600 \mathrm{~mm}$ external diameter and is segmented to a 10 unequal segments. At the middle of each segment a radially aligned tap of $15 \mathrm{~mm}$ diameter is provided to allow the insertion of the different temperature measuring probes. A $50 \mathrm{~mm}$ diameter main cooling water header is used for the distribution of the cooling water to each segment via an $18.5 \mathrm{~mm}$ diameter inlet pipe (15) at the bottom of each segment. Gate valves (16) are located at the entrance of each segment for the purpose of controlling the water flow rates. The volume flow rate of cooling water can be measured using a calibrated orifice meter at the inlet of each segment. The hot water leaves each segment at the top side (17) and its temperature is measured using thermocouple (18) before drained to the sink. The exhaust temperature is measured at port (19). The emissions are measured using gas analyzer (20) at port (21). A schematic diagram of the atomizer and its components are shown in Fig. 2. The atomizer is installed in a burner tube as shown in Fig. 3.

\section{Measuring Instruments}

This section describes the different measuring devices that are used to measure inflame temperature distribution, exhaust temperature, water temperature, air flow rate, emissions and fuel flow rate. The inflame temperature and exhaust gas temperature measurements system consists of thermocouple and position guide. The thermocouple employed in the present study is made of platinum/ (platinum 10\% rhodium) wires of $190 \mu \mathrm{m}$ diameter. The thermocouple wires are supported in a twin-bore ceramic tube having an external diameter of $4 \mathrm{~mm}$. The ceramic tube is placed inside a stainless steel tube of $6 \mathrm{~mm}$ external diameter. The temperature of the hot water at the exit of each furnace segment is measured using calibrated T-type thermocouple located at the exit of each segment. The fuel flow rate, combustion air and atomizing air flow rate are measured using calibrated orifice meter for each. The exhaust gases $\left(\mathrm{CO}\right.$ and $\left.\mathrm{NO}_{\mathrm{x}}\right)$ are measured using calibrated E-instrument gas analyzer.

\section{Results and Discussion}

The heat transfer rate and heat flux to the water jacket of the furnace are calculated from the cooling water temperature measurements according to the following expressions:

$$
\begin{gathered}
\dot{Q}_{w}=\dot{m}_{w} C_{w}\left(\dot{T}_{w, \text { exit }}-T_{w, \text { nlet }}\right) \\
\text { Heat flux }=\frac{\dot{Q}_{w}}{A_{\text {segment }}}
\end{gathered}
$$

where

$\dot{Q}_{w}$ : Heat transfer rate

$\dot{m}_{w}:$ Water mass flow rate,

$C_{w}:$ Specific heat of the water,

$T_{w, \text { exit }}$ : Water exit temperature,

$T_{w, \text { inlet }}:$ Inlet water temperature,

$A_{\text {segment }}$ : Area of each segment of the furnace. 
Figure 4 shows the total heat transfer rate to the water jacket for different values of atomizing air pressure. It can be seen that, decreasing the atomizing air pressure, leads to increasing the amount of heat transferred to the cooling water jacket. This behavior can be interpreted as the increasing in atomizing air pressure leads to decreasing in the flame length as shown in Fig. 5. The decreasing in flame length reduces the radiation heat transfer, hence reducing the total heat transfer rate.

The overall combustion efficiency can be defined as the ratio of the heat transferred to the water jacket and exhaust gases to the fuel energy input. The combustion efficiency can be calculated from the following expression (without taking heat loss from rear and front faces of the furnace):

where

$$
\eta=\frac{\dot{Q}_{w}+\left(\dot{m}_{\text {atom. }}+\dot{m}_{c o m b .}\right) x c_{\text {air }} x\left(T_{\text {ex. }}-T_{\text {air }}\right)}{\dot{m}_{f} x c v}
$$

$\eta$ : Combustion efficiency,

$\dot{m}_{\text {atom. }}$ : Atomizing air mass flow rate,

$\dot{m}_{\text {comb. }}$ : Combustion air mass flow rate,

$c_{\text {air }}$ : Specific heat of air,

$T_{\text {ex. }}$ : Exhaust temperature,

$T_{\text {air }}$ : Inlet air temperature,

$\dot{m}_{f}$ : Fuel mass flow rate,

$c v$ : Fuel heating value.

It is noticed that the increasing the atomizing air pressure decreases the overall combustion efficiency as shown in Fig. 6 and this agree with the heat flux results which discussed earlier.

The emission from the furnace is analyzed and it is found that increasing in atomizing air pressure leads to increasing the air quantity in the flame axis, subsequently leads to increasing in $\mathrm{O}_{2}$ percentage as shown in Fig. 7. The $\mathrm{CO}$ and $\mathrm{NO}_{\mathrm{x}}$ emissions are measured and it is found that the increasing in atomizing air pressure leads to increasing in $\mathrm{CO}$ and $\mathrm{NO}_{\mathrm{x}}$ emissions as shown in Figs. 8 and 9 respectively. The increasing in $\mathrm{O}_{2}$ percentage at the flame center helps in increasing $\mathrm{NO}_{\mathrm{x}}$ emissions. Fig. 10 presents that the overall inflame temperature decreases with increasing the atomizing air pressure, but the temperature increases only in the flame region as the combustion process is improved due to fine droplets.

Figure 11 shows the free visualization of the flame at various atomizing air pressures. It is noticed that increasing of atomizing air pressure leads to shorter, stable flame, and moreover less smoke. This occurs due to increasing of atomizing air pressure improves the atomization process of the fuel, as well as, the swirling effect of atomizing air enhances the mixing of the mixture that generates fine spray subsequently the droplets burn completely in a short distance near the burner tip. Also, it is found that the atomizing air pressure is limited up to 2 bar where at a higher pressure the flame is tends to lift off.

Also, the effect of air to fuel ratio on the fame characteristics and emissions is studied. The air to fuel ratio was changed with the same fuel flow rate. It is noticed that the increasing in air to fuel ratio leads to increasing in $\mathrm{O}_{2}$ emissions as shown in Fig. 12 and decreasing in $\mathrm{CO}_{2}$ emissions as shown in Fig. 13. Also, $\mathrm{CO}$ emissions and $\mathrm{NO}_{\mathrm{x}}$ emissions is decreased as shown in Figs. 14 and 15 respectively. The decreasing in axial temperature as shown in Fig. 16 and decreasing in stack temperature Fig. 17 are the main reason of decreasing $\mathrm{CO}$ and $\mathrm{NO}_{\mathrm{x}}$ emissions. Also, the increasing in $\mathrm{O}_{2}$ percentage helps in increasing $\mathrm{NO}_{\mathrm{x}}$ emissions. 
Figure 18 presents the radial temperature profiles at different axial locations along the combustor. The peak temperature ensues where intense mixing among fuel, primary, and secondary air streams. An almost uniform temperature region occurs in the outer recirculation zone and the temperature declines near the wall of the furnace. This temperature profile starts to flatten with increasing axial distance as this region presents the exhaust gas temperature outer the flame region. Figure 19 shows that increasing in air to fuel ratio leads to decreasing the flame length inside the furnace.

\section{Conclusions}

In the present study, the spray combustion characteristics of the external mixing air assist atomizer was investigated experimentally at different overall air to fuel ratios and different values of atomizing air pressure. Also, the emissions and combustion efficiency is calculated. And the following conclusions were obtained:

- Increasing the atomizing air pressure, decreases the amount of heat transferred to the cooling water jacket in the studied cases.

- The combustion efficiency decreases with increasing atomizing air pressure at the same air to fuel ratio.

- Increasing in atomizing air pressure leads to increasing in $\mathrm{CO}$ and $\mathrm{NO}_{\mathrm{x}}$ emissions.

- Increasing in air to fuel ratio leads to decreasing in $\mathrm{CO}$ and $\mathrm{NO}_{\mathrm{x}}$ emissions.

- Increasing atomizing air pressure and air to fuel ratio decreases the flame length.

\section{References}

[1] S. C. Rah, "Combustion of liquid fuels and pollutant formation: A review Part I. Liquid fuel combustion process," Korean J. Chem. Eng., vol. 1, no. 2, pp. 89-97, 1984.

[2] M. Abu-Qudais and G. Okasha, "Diesel fuel and olive-cake slurry: Atomization and combustion performance," Appl. Energy, vol. 54, no. 4, pp. 315-326, 1996.

[3] M. Costa, P. Costen, and F. C. Lockwood, "Detailed Measurements in a Heavy Fuel OilFired Large-Scale Furnace," Combust. Sci. Technol., vol. 75, pp. 129-154, 1991.

[4] Y. Onuma and M. Ogasawara, "Studies on a spray combustion flame," in Symposium (International) on Combustion, vol. 15, no. 1, pp. 453-465, 1975.

[5] A. Breña de la Rosa, A. Sobiesiak, and T. A. Brzustowski, "The influence of fuel properties on drop-size distribution and combustion in an oil spray," in Symposium (International) on Combustion, vol. 21, no. 1, pp. 557-566, 1988.

[6] R. J. Sornek, R. Dobashi, and T. Hirano, "Effect of turbulence on vaporization, mixing, and combustion of liquid-fuel sprays," Combust. Flame, vol. 120, no. 4, pp. 479-491, 2000 .

[7] C. Pereira, G. Wang, and M. Costa, "Combustion of biodiesel in a large-scale laboratory furnace," Energy, vol. 74, pp. 950-955, 2014.

[8] M. B. Padwal and D. P. Mishra, "Experimental Characterization of Gelled Jet A1 Spray Flames," Flow, Turbul. Combust., vol. 97, no. 1, pp. 295-337, 2016.

[9] A. Verdier, J. M. Santiago, A. Vandel, S. Saengkaew, G. Cabot, G. Grehan, and B. Renou, "Experimental study of local flame structures and fuel droplet properties of a spray jet flame," Proc. Combust. Inst., 2016.

[10] L. S. Liu, H. Yang, X. Gou, R. Duan, and Y. Yuan, "Experimental investigations on the spray combustion produced by effervescent atomizers," in Proceedings of International Conference on Computer Distributed Control and Intelligent Environmental Monitoring, CDCIEM, pp. 305-311, 2012.

[11] F. El-Mahallawy and S. Habik, Fundamentals and Technology of Combustion, 1st ed. Elsevier, 2002. 
[12] A. Lefebvre and D. Ballal, Gas Turbine Combustion: Alternative Fuels and Emissions, 3rd ed. Taylor \& Francis, 2010.

[13] J. M. Ballester and C. Dopazo, "Experimental Study of the Influence of Atomizatio n Characteristics on the Combustion of Heavy Oi 1," Combust. Sci. Technol., vol. 103, pp. 235-263, 1994.

[14] M. Õ. Abu-qudais, "Performance and emissions characteristics of a cylindrical water cooled furnace using non-petroleum fuel," Energy Convers. Manag., vol. 43, pp. 683691, 2002.

[15] A. Barreiros, M. C. Carvalho, M. Costa, and F. C. Lockwood, "Prediction of the Near Burner Region and Measurements of NOx , and Particulate Emissions in Heavy Fuel Oil Spray Flames," Combust. Flame, vol. 92, pp. 231-240, 1993.

[16] S. B. Hosseini, K. Bashirnezhad, A. R. Moghiman, Y. Khazraii, and N. Nikoofal, "Experimental Comparison of Combustion Characteristic and Pollutant Emission of Gas oil and Biodiesel," Int. J. Mech. Aerospace, Ind. Mechatron. Manuf. Eng., vol. 4, no. 12, pp. 1372-1375, 2010.

[17] B. A. Akash, "Combustion and Emission Investigation of Diesel Fuel and Kerosene Blends," Res. J. Appl. Sci. Eng. Technol., vol. 10, no. 6, pp. 618-622, 2015.

[18] A. K. Gupta, "Effect of swirl and flow distribution on the spray flame characteristics," pp. 1300-1305, 2000.

[19] R. Aftel, A. K. Gupta, C. Cook, and C. Presser, "Gas property effects on droplet atomiation and combustion in an air-assist atomier," in In Twenty-Sixth Symposium (International) on Combustion, vol. 26, no. 1, pp. 1645-1651, 1996.

[20] C. Presser, A. K. Gupta, and H. G. Semerjian, "Aerodynamic Characteristics of Swirling Spray Flames : Pressure-Jet Atomizer," Combust. Flame, vol. 92, pp. 25-44, 1993.

Table (1) Physical properties of diesel fuel

\begin{tabular}{|c|c|c|c|c|c|}
\hline Test & & Test meth & & & Results \\
\hline \multirow{2}{*}{$\begin{array}{ll}\text { Relative } & \text { Density } \\
@ 60 / 60^{\circ} \mathrm{F} & \\
\end{array}$} & & \multirow{2}{*}{$\begin{array}{l}\text { ASTM } \\
\text { ESS-80 }\end{array}$} & \multirow{2}{*}{ D-1298 } & $(\mathrm{MIN})$ & 0.82 \\
\hline & & & & $(\mathrm{MAX})$ & 0.87 \\
\hline Flash Point (P.M.C) & ${ }^{\circ} \mathrm{C}$ & $\begin{array}{l}\text { ASTM } \\
\text { ESS-177 }\end{array}$ & D-93 & (MIN) & 55 \\
\hline \multirow{2}{*}{$\begin{array}{l}\text { Viscosity Kinematic } \\
@ 40^{\circ} \mathrm{C}\end{array}$} & \multirow{2}{*}{ CST } & ASTM & \multirow{2}{*}{ D-445 } & $(\mathrm{MIN})$ & 1.6 \\
\hline & & ESS-1390 & & (MAX) & 7 \\
\hline $\begin{array}{ll}\text { Gross } & \text { Calorific } \\
\text { Value } & \end{array}$ & $\mathrm{MJ} / \mathrm{kg}$ & $\begin{array}{l}\text { ASTM } \\
\text { ESS-420 }\end{array}$ & D-4868 & (MIN) & 44.3 \\
\hline Total sulphur & $\%$ wt & $\begin{array}{l}\text { ASTM } \\
\text { ESS-178 }\end{array}$ & D-2622 & (MAX) & 1 \\
\hline Conradson carbon & $\%$ wt & $\begin{array}{l}\text { ASTM } \\
\text { ESS-83 }\end{array}$ & D-189 & (MAX) & 0.1 \\
\hline Ash content & $\%$ wt & $\begin{array}{l}\text { ASTM } \\
\text { ESS-81 }\end{array}$ & D-482 & (MAX) & 0.01 \\
\hline
\end{tabular}




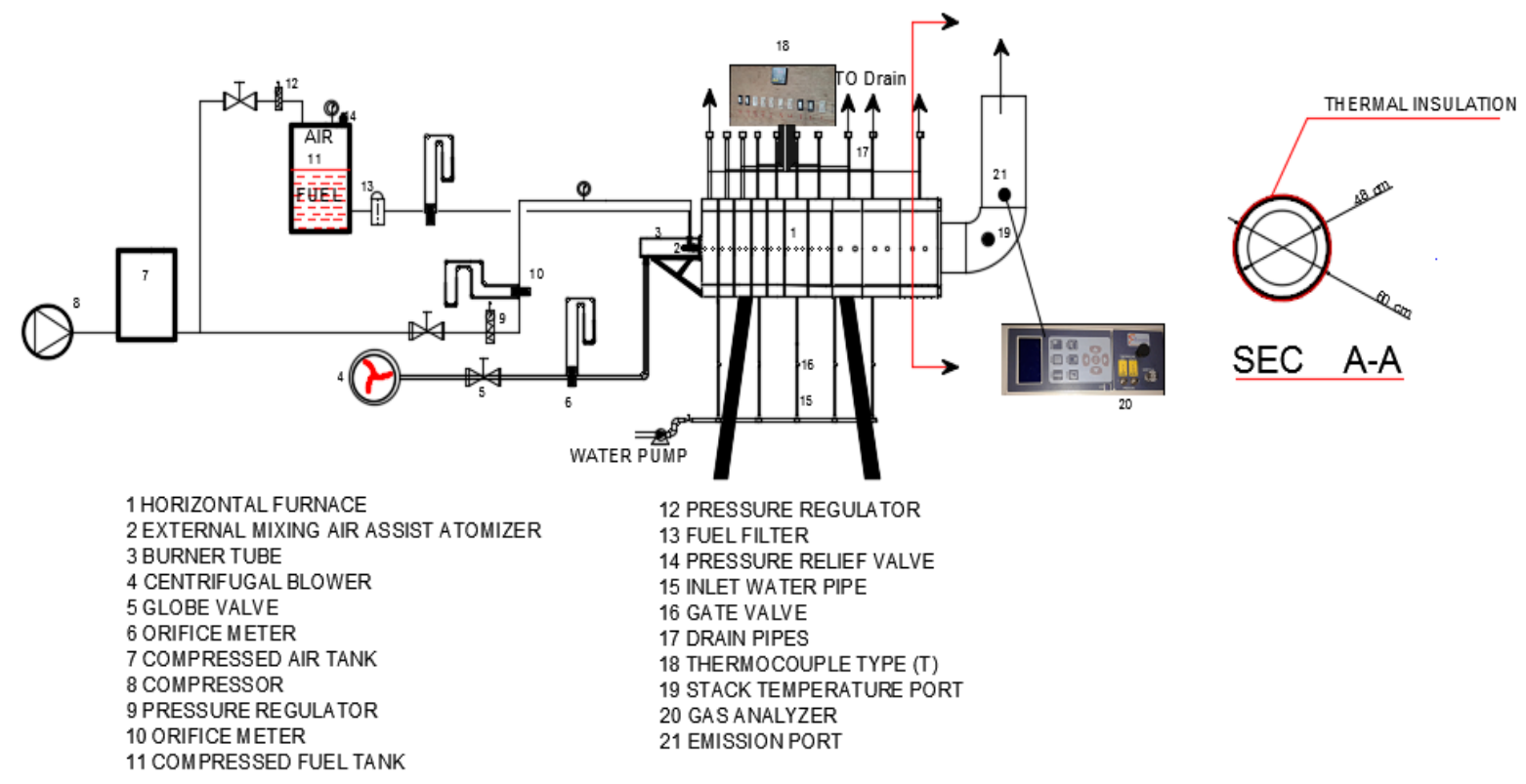

Fig. 1. Schematic diagram of an experimental test rig

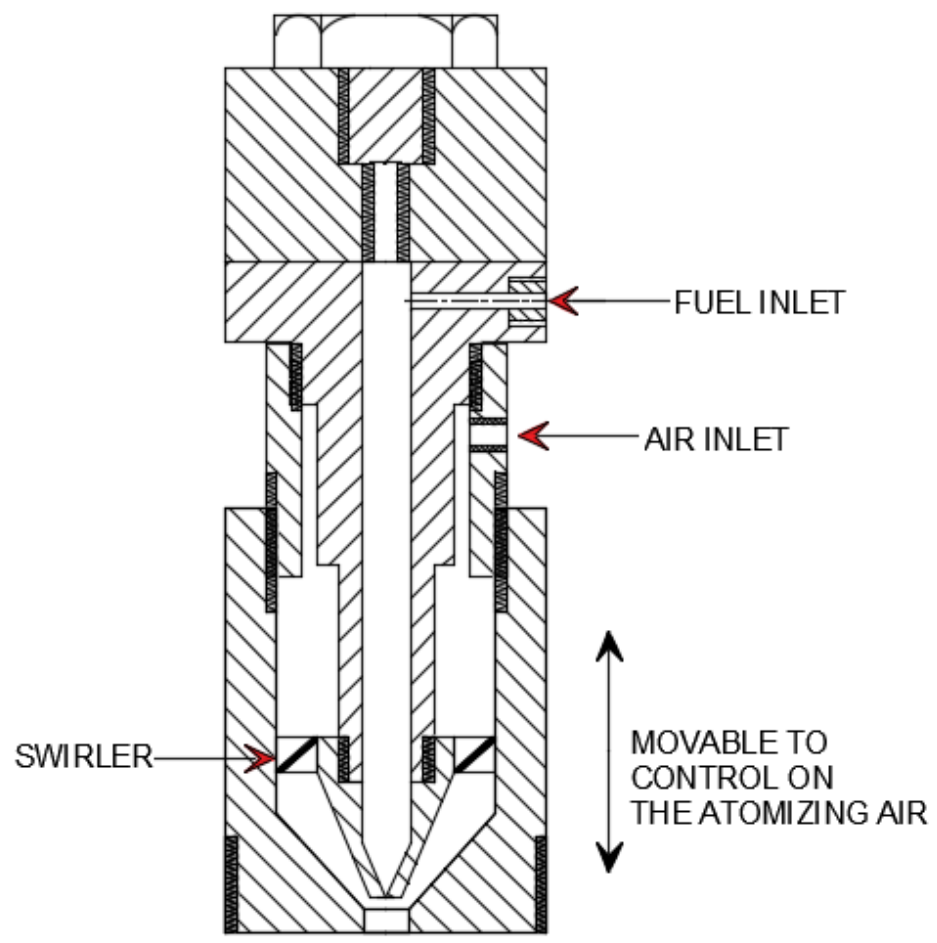

Fig. 2. An external mixing air assist atomizer 


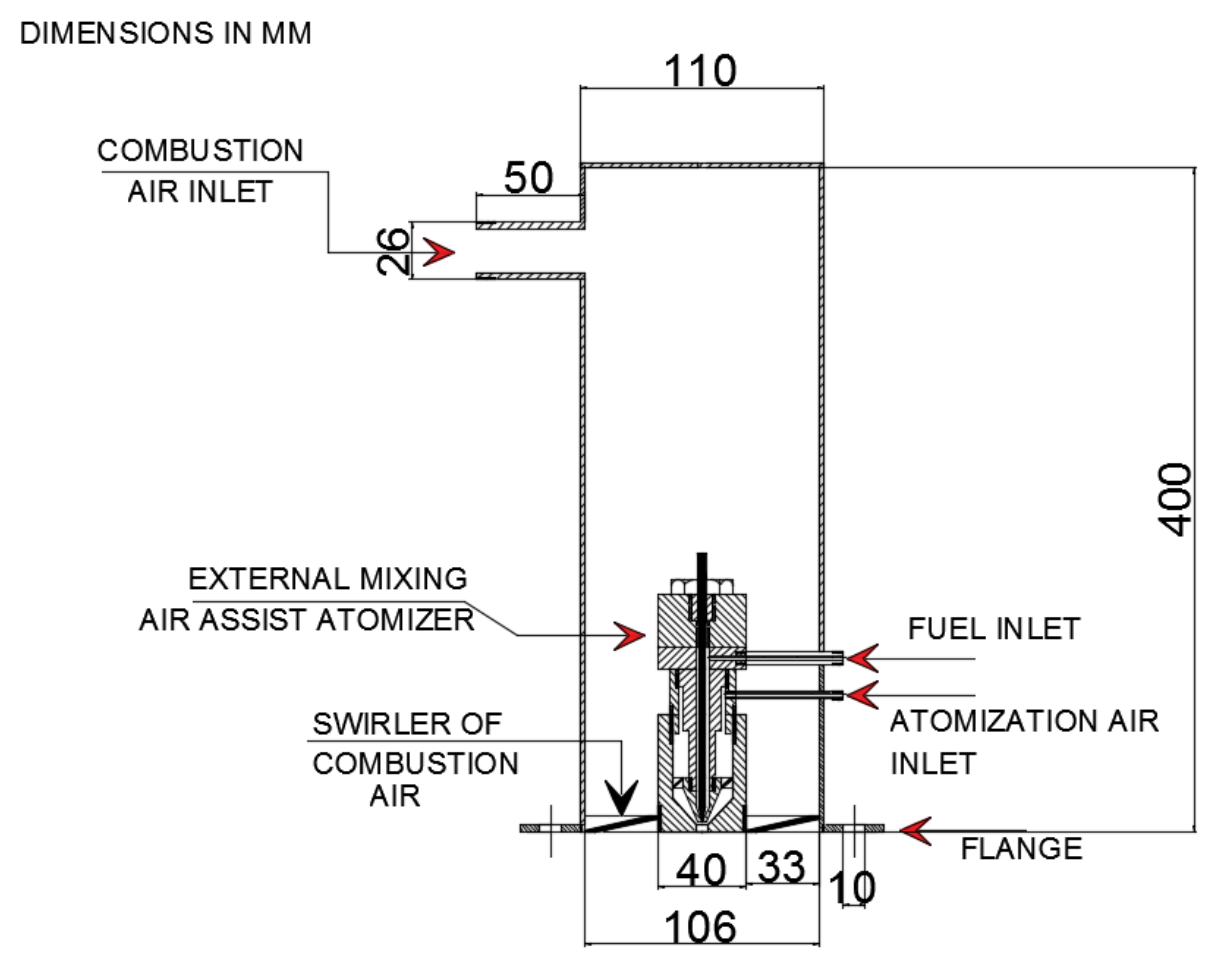

Fig. 3. Burner assembly

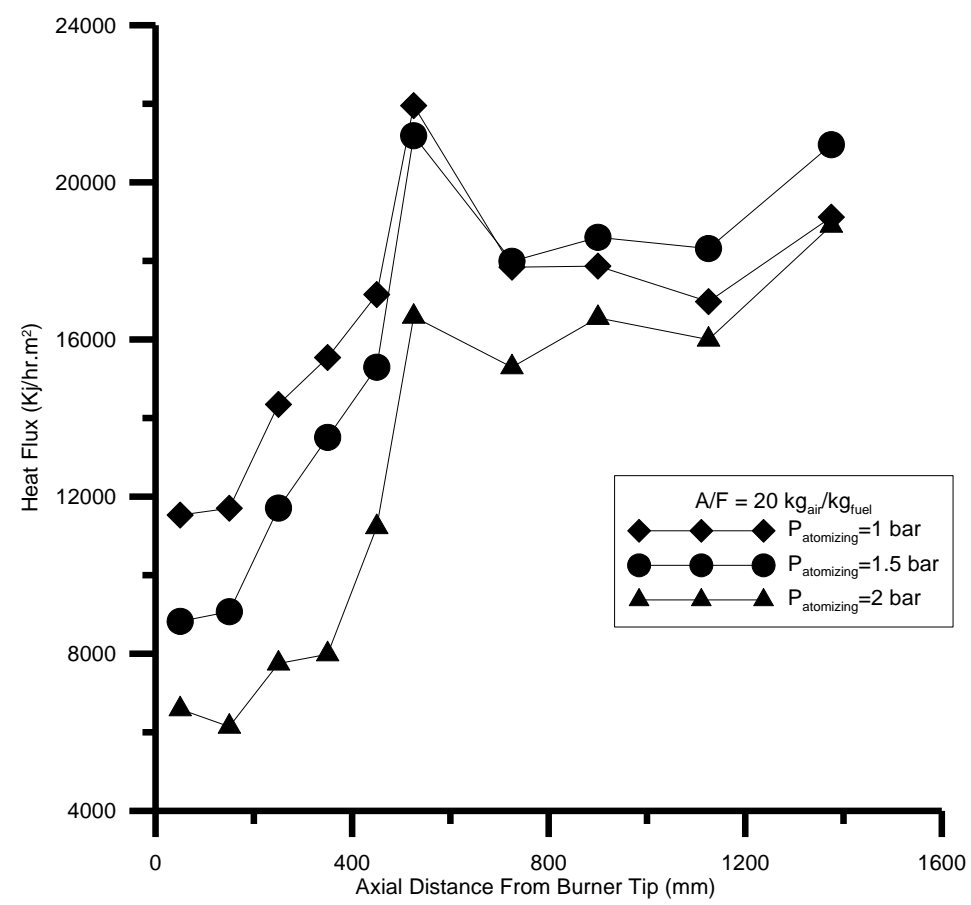

Fig. 4. Effect of atomizing air pressure on heat flux at air to fuel ratio $20 \mathrm{~kg}_{\text {air }} / \mathrm{kg}_{\text {fuel }}$ 


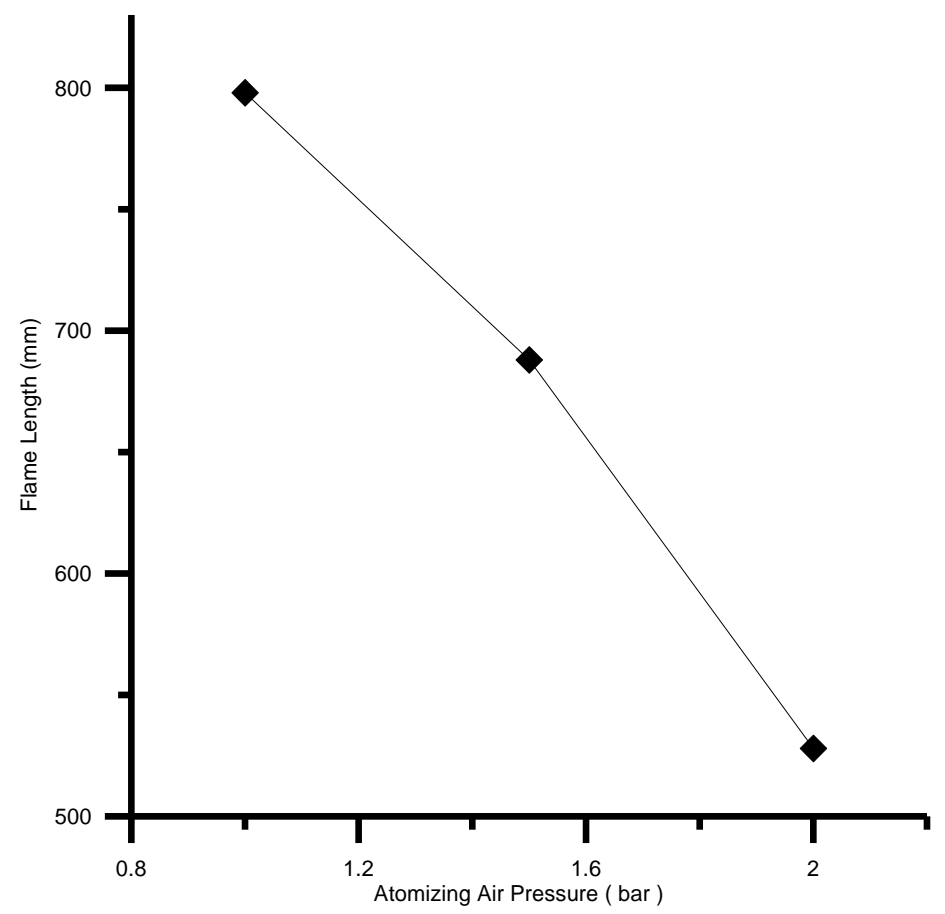

Fig. 5. Effect of atomizing air pressure on flame length at air to fuel ratio $20 \mathrm{~kg}$ air $/ \mathrm{kg}_{\text {fuel }}$

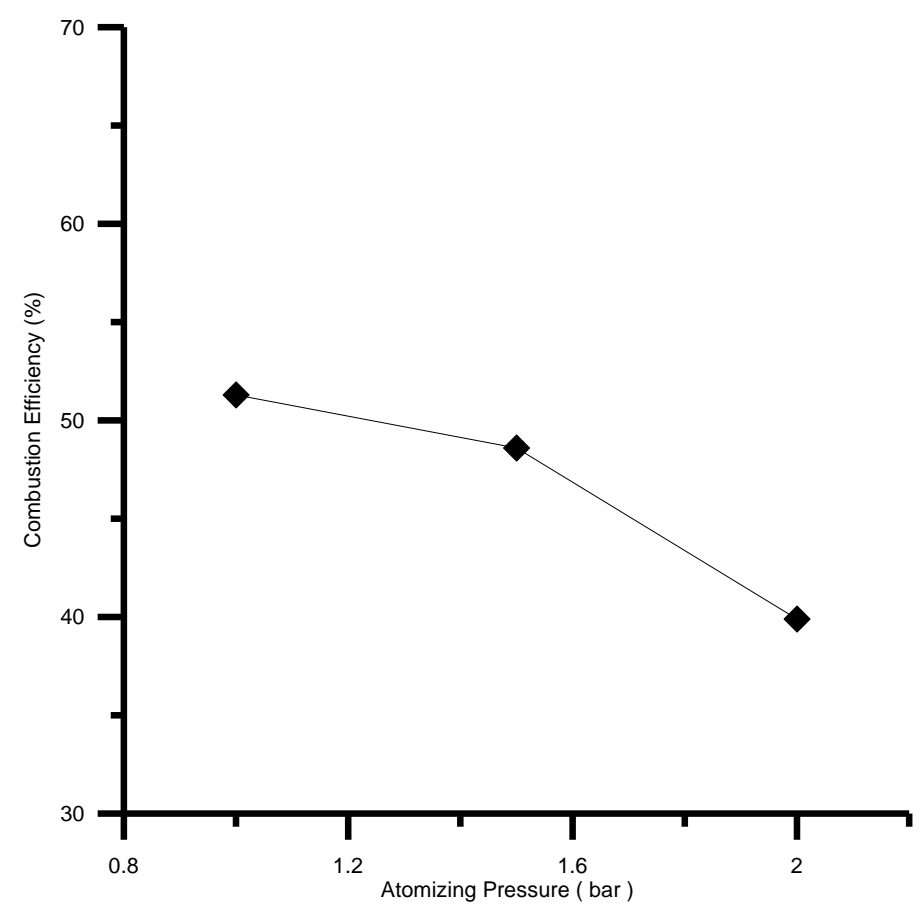

Fig. 6. Effect of atomizing air pressure on combustion efficiency at air to fuel ratio $20 \mathrm{~kg}_{\text {air }} / \mathrm{kg}_{\text {fuel }}$ 


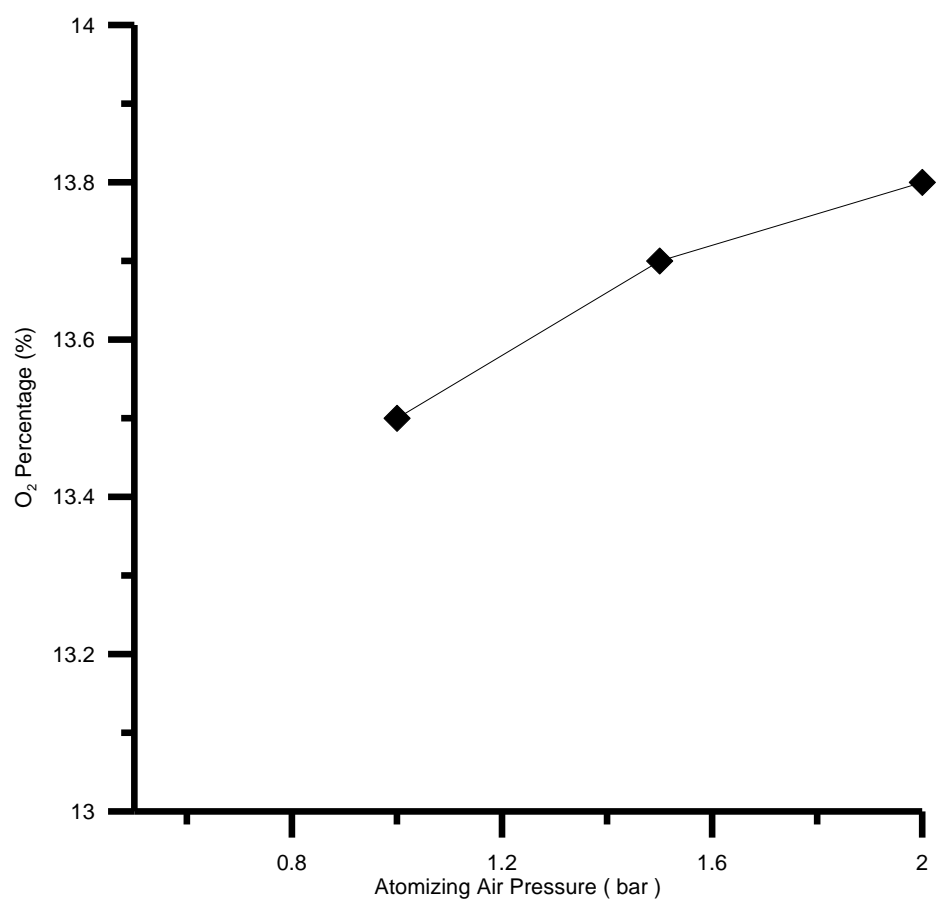

Fig. 7. Effect of atomizing air pressure on $\mathrm{O}_{2}$ concentration at air to fuel ratio $20 \mathrm{~kg}_{\text {air }} / \mathrm{kg}_{\text {fuel }}$

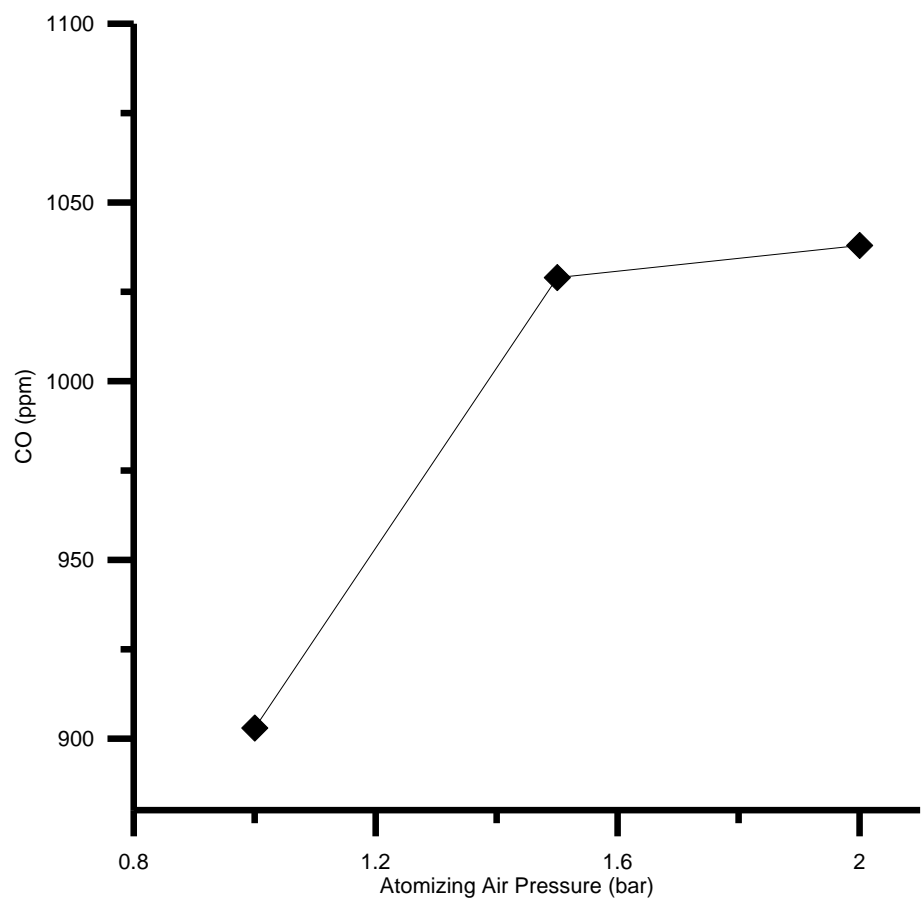

Fig. 8. Effect of atomizing air pressure on $\mathrm{CO}$ emissions at air to fuel ratio $20 \mathrm{~kg}_{\text {air }} / \mathrm{kg}_{\text {fuel }}$ 


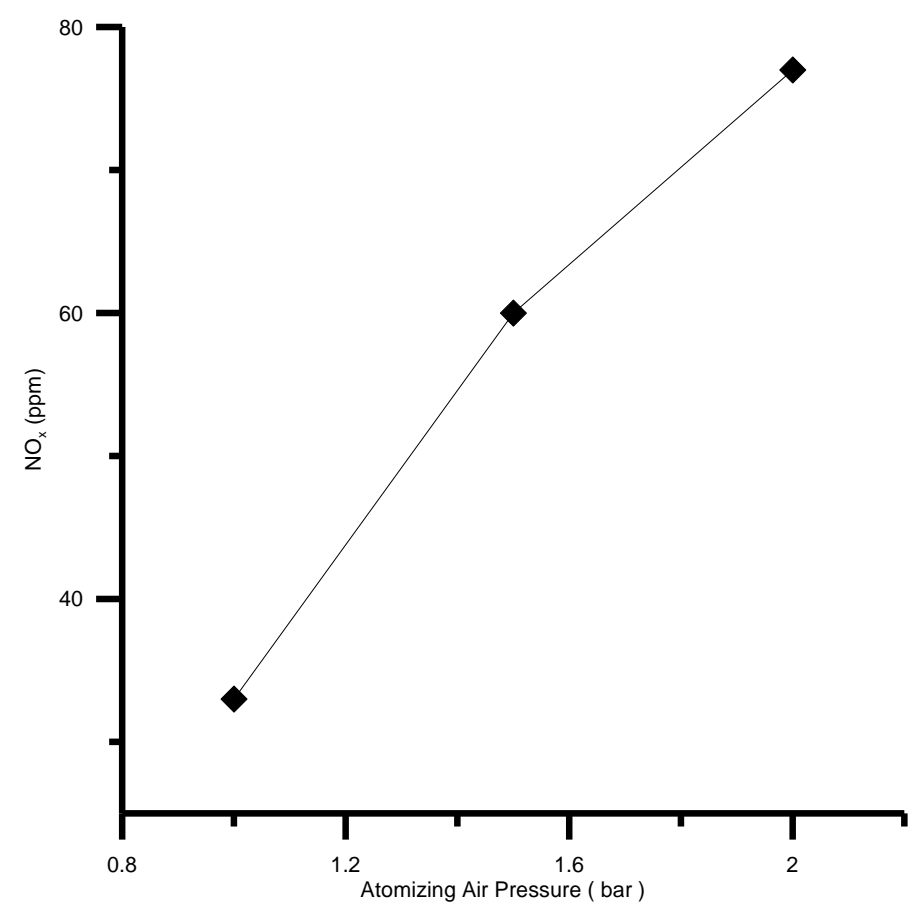

Fig. 9. Effect of atomizing air pressure of $\mathrm{NO}_{\mathrm{x}}$ emissions at air to fuel ratio $20 \mathrm{~kg}_{\text {air }} / \mathrm{kg}_{\text {fuel }}$

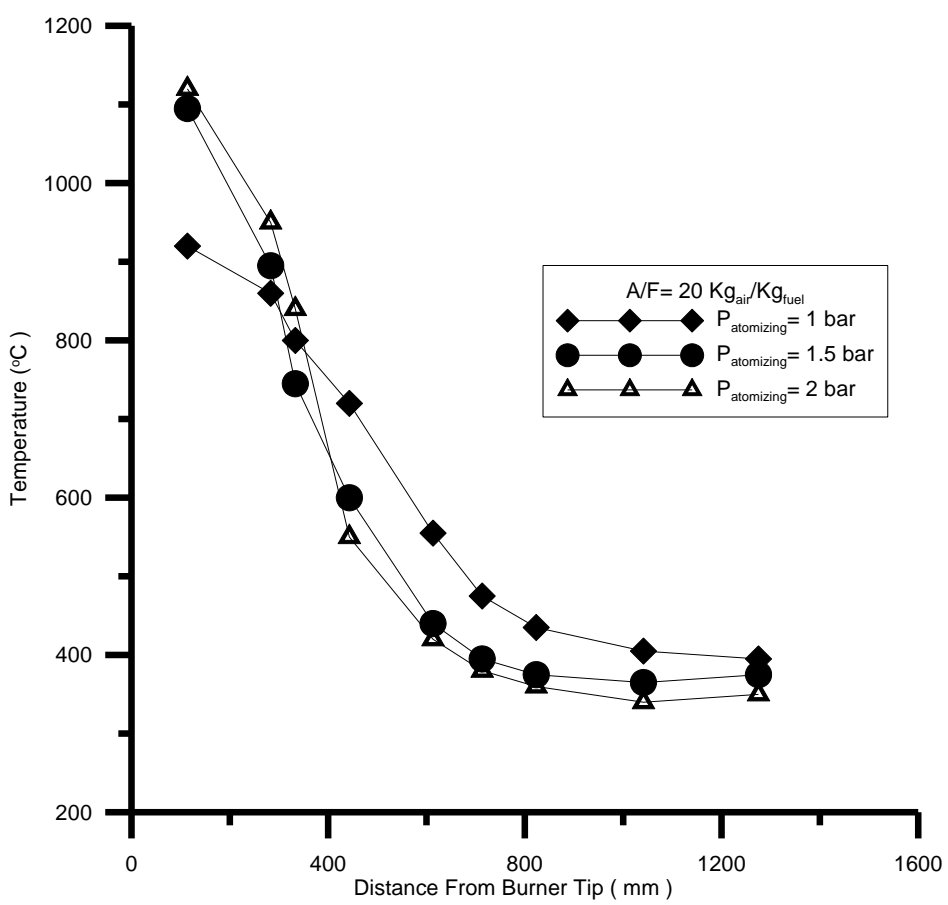

Fig. 10. Effect of atomizing air pressure on inflame temperature at air to fuel ratio $20 \mathrm{~kg}$ air $/ \mathrm{kg}_{\text {fuel }}$ 


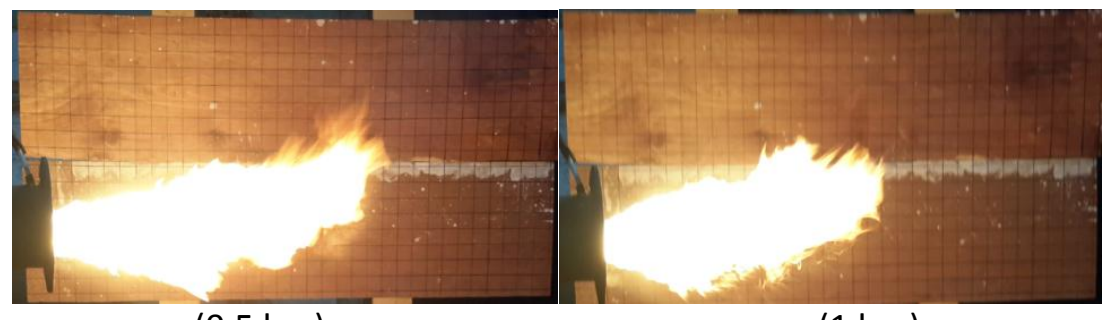

(0.5 bar)

(1 bar)

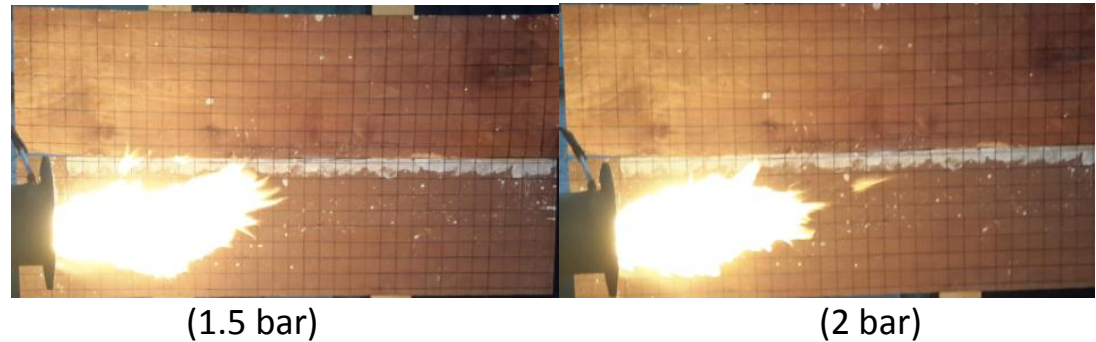

Fig. 11. Free visualization of spray flame at various values of atomizing air pressure

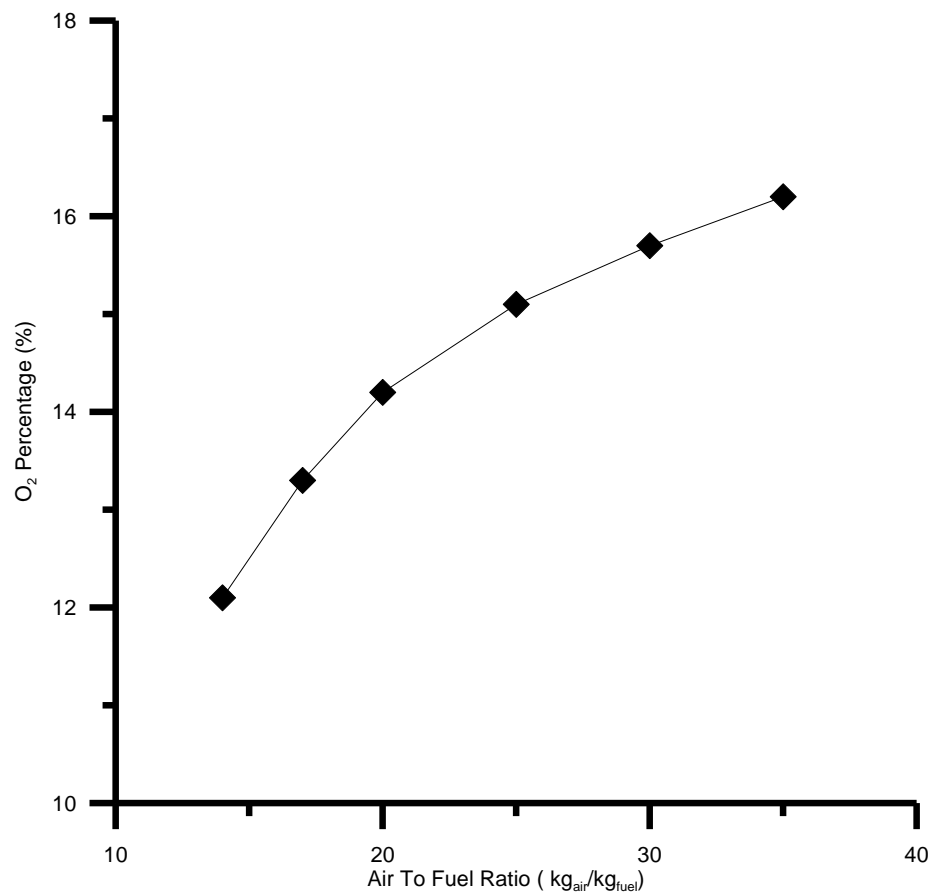

Fig. 12. Effect of air to fuel ratio on $\mathrm{O}_{2}$ concentration at atomizing pressure $1.5 \mathrm{bar}$ 


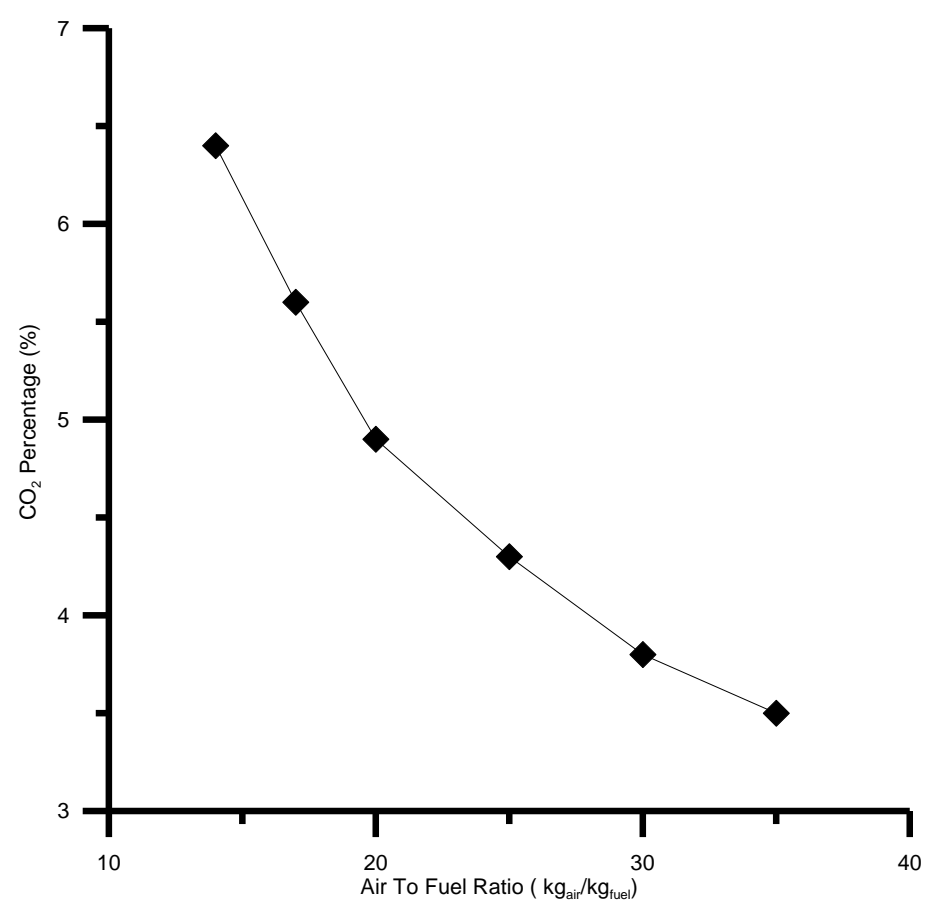

Fig. 13. Effect of air to fuel ratio on $\mathrm{CO}_{2}$ emissions at atomizing pressure $1.5 \mathrm{bar}$

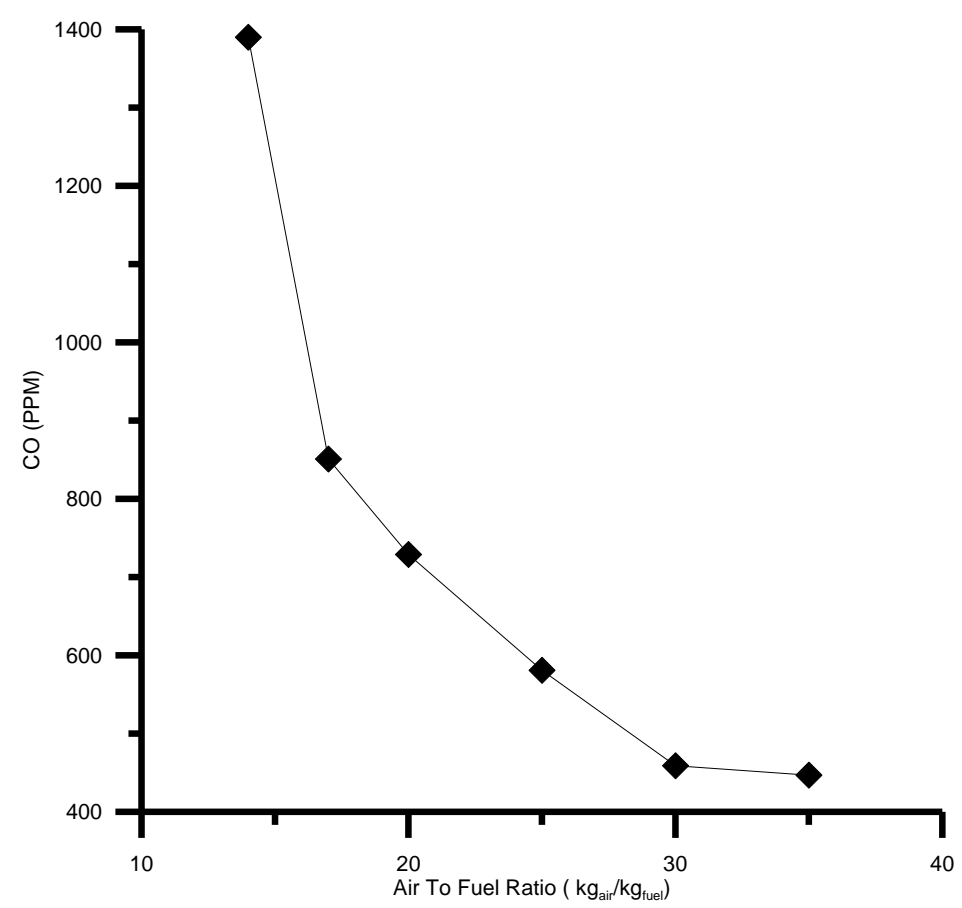

Fig. 14. Effect of air to fuel ratio on CO emissions at atomizing pressure $1.5 \mathrm{bar}$ 


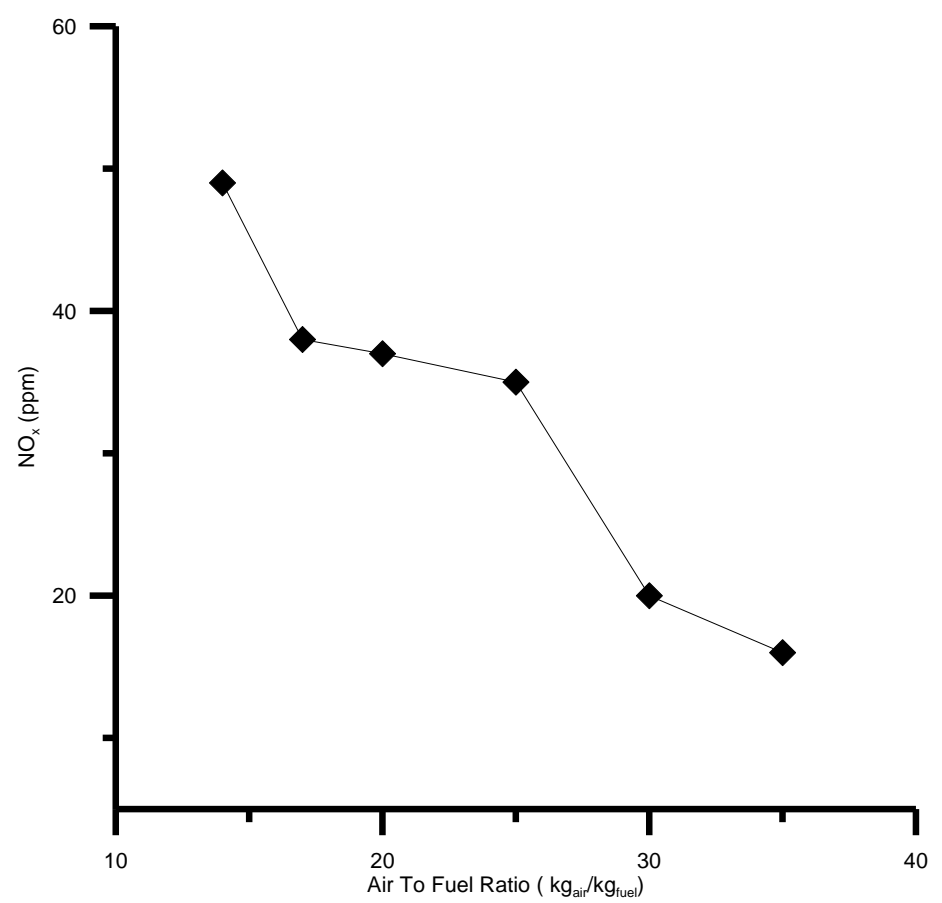

Fig. 15. Effect of air to fuel ratio on $\mathrm{NO}_{\mathrm{x}}$ emissions at atomizing pressure 1.5 bar.

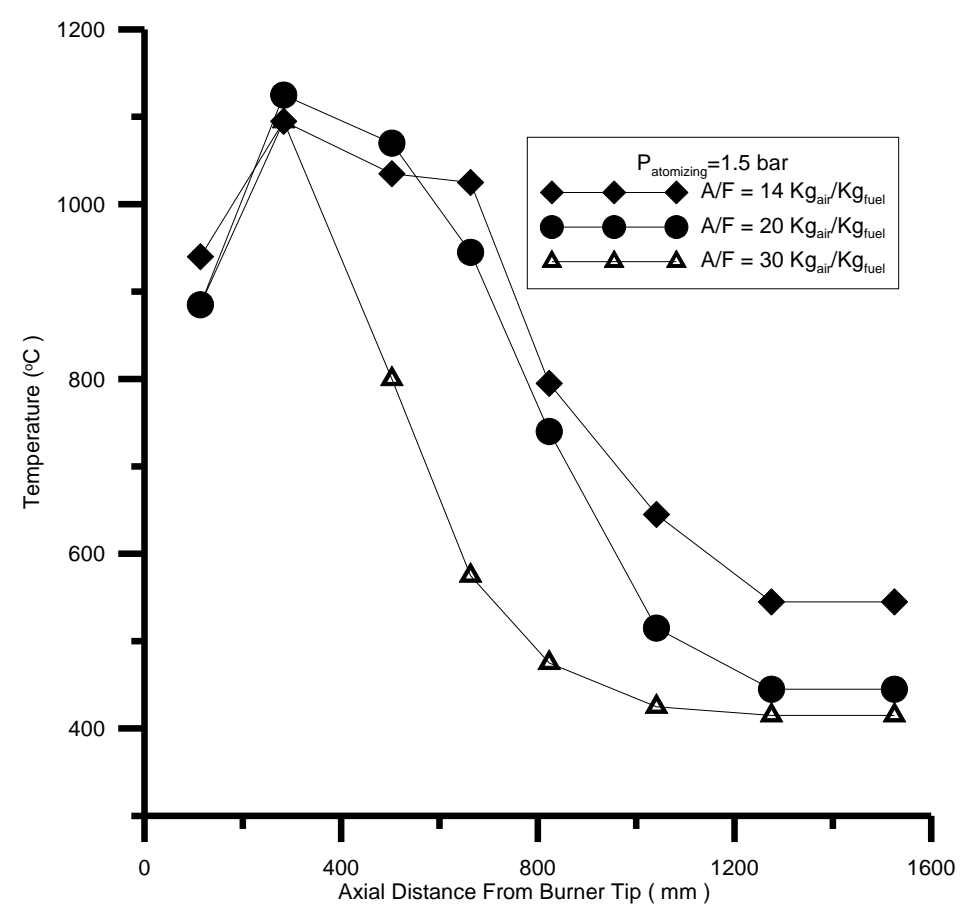

Fig. 16. Effect of air to fuel ratio on the axial inflame temperature at atomizing air pressure $1.5 \mathrm{bar}$ 


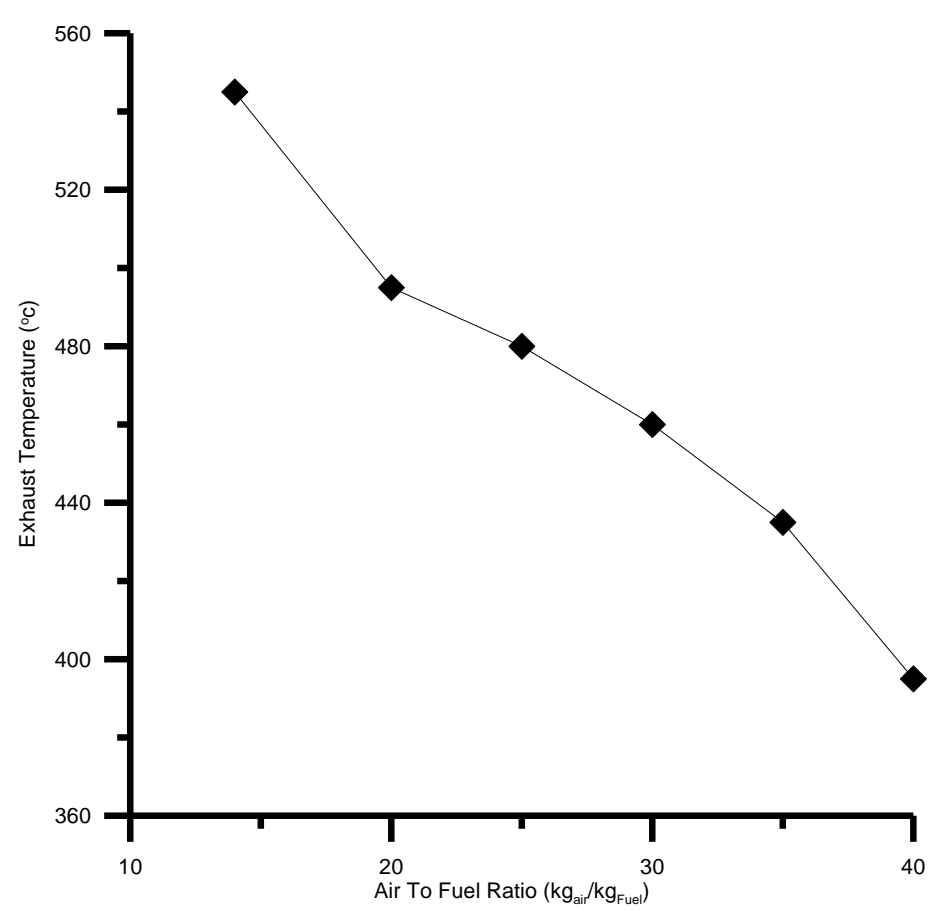

Fig. 17. Effect of air to fuel ratio on the exhaust gas temperature at atomizing pressure 1.5 bar

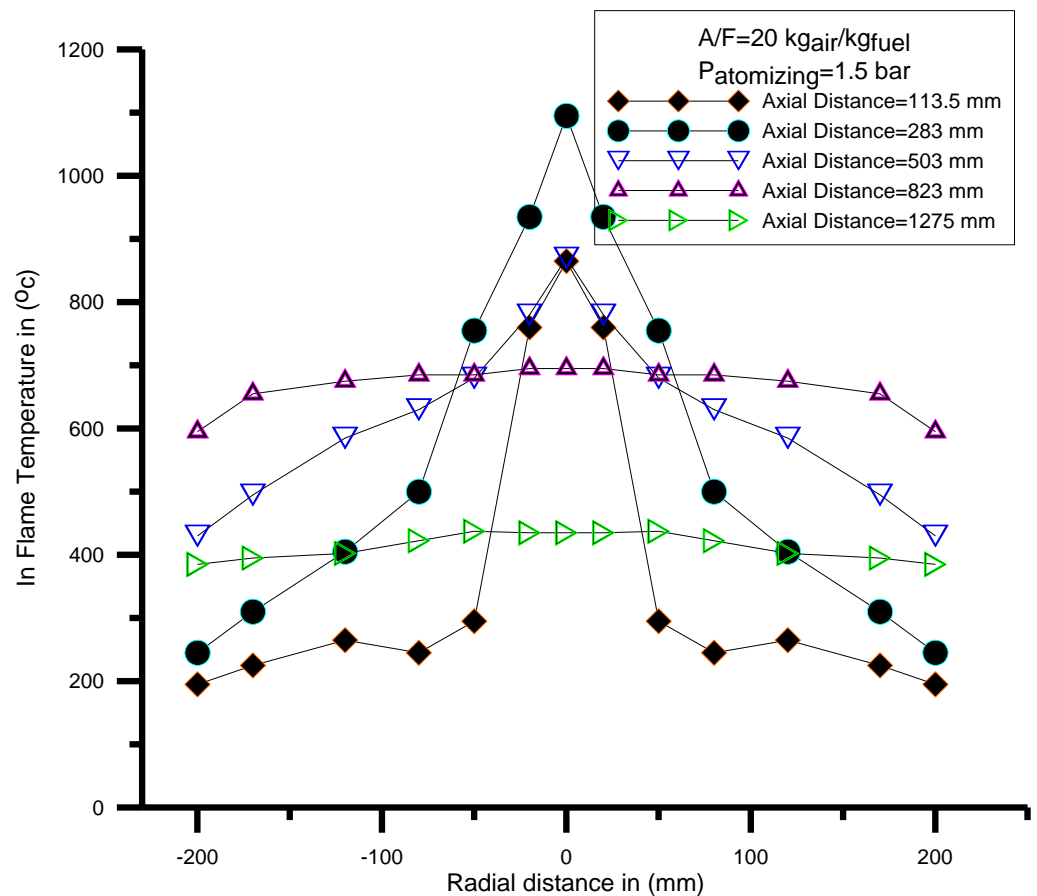

Fig. 18. Radial distribution of inflame temperature at different axial locations. 


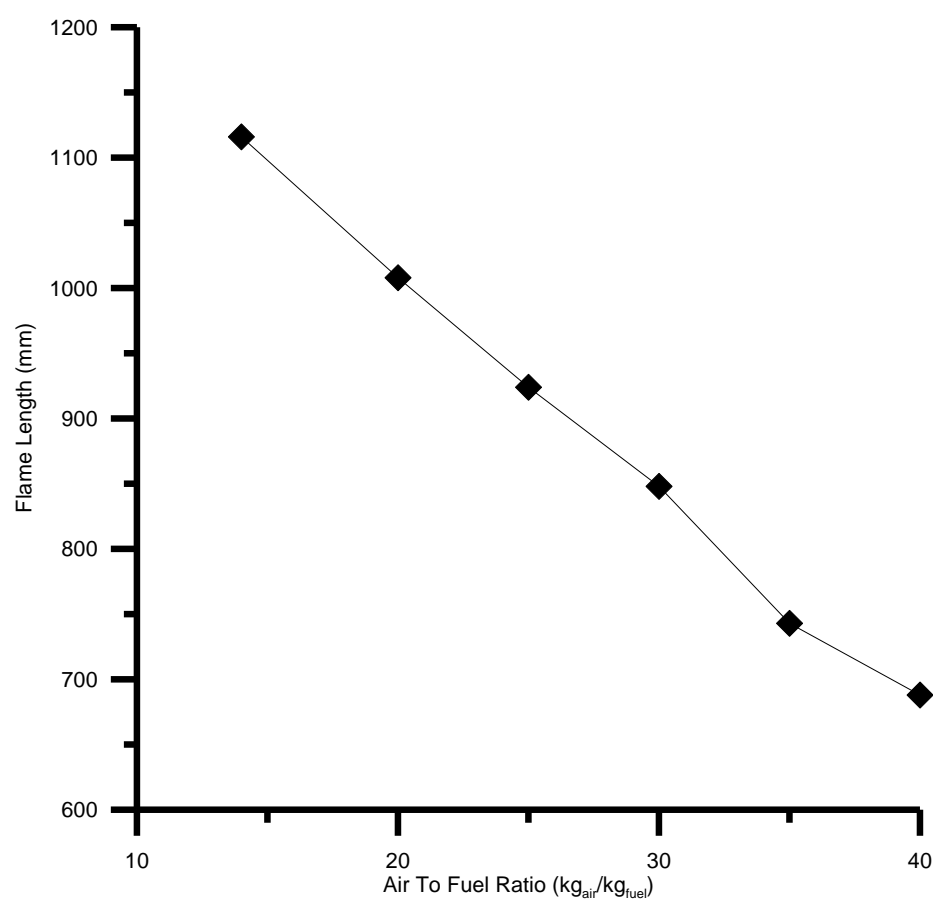

Fig. 19. Effect of air to fuel ratio on confined flame length at atomizing pressure $1.5 \mathrm{bar}$ 